\title{
Hemodiyaliz Hastalarının Demografik Özelliklerine Göre Beslenme Durumlarının Değerlendirilmesi
}

\author{
Evaluation of Nutritional Status of Hemodialysis Patients According to Demographic \\ Characteristics
}

\author{
Kübra Damla Ekenci' ${ }^{1}$, Perim F. Türker ${ }^{2}$, Aydan Ercan ${ }^{3}$
}

Geliş tarihi/Received: 07.11.2019 • Kabul tarihi/Accepted: 29.12.2019

\section{ÖZET}

Amaç: Bu çalışmanın amacı, hemodiyaliz hastalarının beslenme alışkanlıklarının belirlenmesi ve sosyo-demografik özellikleri ile beslenme durumları arasındaki ilişkinin irdelenmesidir.

Bireyler ve Yöntem: Çalışma 23-85 yaş arasında 128 (71 kadın, \%55.5) hemodiyaliz hastası üzerinde yürütülmüştür. Hastaların demografik özellikleri ve beslenme alışanlıkları anketle belirlenmiştir. Antropometrik ölçümleri araştırmacı tarafından alınmış ve biyokimyasal parametreler hasta dosyasından elde edilmiştir. Subjektif Global Değerlendirme (SGD), Nutrisyonel Risk Taraması-2002 (NRS-2002) ve Malnütrisyon Inflamasyon Skoru (MİS) kullanılarak malnütrisyon durumu saptanmıştır.

Bulgular: SGD’ye göre hastaların \%8.6'sı ağır, \%15.6’sı ise hafif-orta derecede malnütrisyonlu iken, NRS-2002'ye göre hastaların \%21.9'unun beslenme riskine sahip olduğu belirlenmiştir. Malnütrisyon inflamasyon skoruna göre (Mís) kadın ve erkek hastaların Mis ortanca değeri sırasıyla 6 ve 5 puan olarak bulunmuştur (p>0.05). NRS-2002’ye göre malnütrisyon riski olan hastaların \%64.2'si ilkokul ve altı eğitim düzeyine sahiptir. SGD'ye göre ise hafif-orta derece malnütrisyonlu olan hastaların \%50'sinin ilkokul ve altı eğitim düzeyine sahip olduğu, ağır derece malnütrisyonlu olan hastaların \%45.5’inin okur yazar olmadığı, \%36.4’ünün ilkokul mezunu olduğu saptanmıştır. Hastaların eğitim düzeylerine göre malnütrisyon durumunun istatistiksel olarak farklı olduğu bulunmuştur $(\mathrm{p}<0.05)$. Mís puanları ile yaş, eğitim ve gelir düzeyleri arasında ilişki saptanmamıştır ( $\mathrm{p}>0.05)$.

Sonuç: Hemodiyaliz hastalarının büyük bir çoğunluğunun eğitim ve gelir düzeyi düşüktür. Eğitim düzeyi düşük hastalarda malnütrisyon riski ve varlığı daha yüksektir. Hastalarda malnütrisyon riskinin belirlenmesinde ve yapılacak beslenme müdahalelerinde hastaların sosyo-demografik özelliklerinin de dikkate alınmasının gerekli olduğu düşünülmektedir.

Anahtar kelimeler: Hemodiyaliz, beslenme durumu, malnütrisyon, demografik özellikler

\begin{abstract} between demographic characteristics and nutritional status.

1. İletişim/Correspondence: Gazi Üniversitesi Sağlık Bilimleri Fakültesi, Beslenme ve Diyetetik Bölümü, Ankara, Türkiye

E-posta: damlaekenci211@gmail.com • ำ https://orcid.org/0000-0001-7368-1060
\end{abstract}

Aim: To determine the nutritional habits in patients receiving hemodialysis treatment. and to evaluate the relationship

Subjects and Methods: The study was conducted on 128 hemodialysis patients (71 female, 55.5\%) aged between 23-85 years.

2. Başkent Üniversitesi, Sağllk Bilimleri Fakültesi, Beslenme ve Diyetetik Bölümü, Ankara, Türkiye • (1) https://orcid.org/0000-0002-4254-3711

3. Trakya Üniversitesi, Sağlık Bilimleri Fakültesi, Beslenme ve Diyetetik Bölümü, Edirne, Türkiye - (1) https://orcid.org/0000-0003-1132-3908 
Demographic characteristics and nutritional habits were determined with a questionnaire. Anthropometric measurements were evaluated and biochemical parameters were recorded from patient's files. Subjective Global Assesment (SGA), Nutrition Risk Screening (NRS-2002) and Malnutrition Inflammation Score (MIS) tests were performed to evaluate malnutrition status of the patients.

Results: According to SGA, $8.6 \%$ of the patients had severe and $15.6 \%$ had mild to moderate malnutrition, while $21.9 \%$ of patients had risk of malnutrition detected by NRS-2002. Median MIS values of female and male patients were 6 and 5 points, respectively ( $p>0.05$ ). From patients who were at risk of malnutrition according to NRS-2002, $64.2 \%$ had an education level of primary school. Half of the patients who were mildly or moderately malnourished according to SGD also had an education level of primary school, while $45.5 \%$ and $36.4 \%$ of severly malnourished patients were found to be illiterate and primary school graduates, respectively. There was a significant difference in malnutrition status of patients according to education level $(\mathrm{p}<0.05)$. However, there was no correlation between MIS scores and age, education and level of income $(p>0.05)$.

Conclusion: The vast majority of hemodialysis patients have low education and income level. The risk and presence of malnutrition is higher among patients with low educational level. It is necessary to consider socio-demographic characteristics of patients during evaluation of malnutrition risk, as well as implementation of nutritional interventions.

Keywords: Hemodialysis, nutritional status, malnutrition, demographic characteristics

\section{Gíriş}

Kronik böbrek hastalığı (KBH) dünyada ve ülkemizde yaygın olarak görülen önemli bir halk sağlığı sorunudur. Erken saptandığında önlenebilir veya ilerlemesi geciktirilebilir olmasına karşın, farkındalığının ve erken tanısının düşük olması nedeniyle birçok olguda hastalığın ortaya çıktığı fark edilmemektedir (1). Amerikan Ulusal Sağlık ve Beslenme Araştırması (NHANES) 2009-2014 çalışması verilerine göre KBH'ın üçüncü ve dördüncü evresinde olan 20 yaş ve üzeri yetişkin hastada farkındalık oranı 2009-2010 yllları arasında \%9.7, 2011-2012 ylları arasında \%12.6, 2013-2014 yılları arasında \%12.4 olarak saptanmıştır (2). Türkiye'de ise farkındalık düzeyi daha düşüktür. Türk Nefroloji Derneği (TND) tarafından yapılan Türkiye Kronik Böbrek Hastalığı Prevalans Çalışması (CREDIT)'na göre ülkemizde erişkinlerin \%15.7'sinde $\mathrm{KBH}$ bulunduğu ve $\mathrm{KBH}$ farkındalığının \%2'nin altında olduğu rapor edilmiştir (3).

Kronik böbrek yetmezliğinde (KBY); üremik belirtilerin kontrol altına alınarak komplikasyonların azaltılması ve hastalığın seyrinin yavaşlatılması amacıyla diyaliz tedavisi ve renal transplantasyon uygulanmaktadır (3-5). Türkiye 2017 yllı Ulusal Nefroloji, Diyaliz ve Transplantasyon Kaylt Sistemi
Raporu'na göre en sık (\%75.8) kullanılan renal replasman tedavisi hemodiyalizdir. Diyalize giren hasta sayısında yıllar içinde kararlı bir artış trendi olsa da, son yıllardaki veriler bir plato oluşumunun başladığını düşündürmektedir (6).

Protein enerji malnütrisyonu (PEM), KBY olan hastalarda sık görülmekle birlikte, morbidite ve mortaliteyi arttıran en önemli risk faktörüdür (7-9). Malnütrisyonu saptamak için kullanılan yöntemlere göre farklılık gösterse de, hemodiyaliz (HD) hastalarında PEM'in görülme sılıl̆ğını \%20-60 arasında değiştiği gösterilmiştir (10-13).

Amerika ve Avrupa'da düşük sosyo-ekonomik düzeye sahip bireylerin SDBY tanı alma sıklığı daha fazladır. Bu bireylerin sağkalım oranlarının daha düşük olduğu görülmüştür $(15,16)$. Sosyo-ekonomik durumun belirlenmesi, kullanılan indekslere, belirteç ve tanımlamadaki farklılıklara göre değişmektedir. Sosyo-ekonomik durumun belirlenmesinde sıklıkla kullanılan ölçütler bireyin gelir durumu, refah düzeyi, eğitim durumu ve mesleği ile sinırlı olmakla beraber son çalışmalar yaşanılan semt ve çevresel koşullar gibi ekolojik özelliklerin de sağlığın sosyal belirleyicisi olarak değerlendirilmesi gerektiğini göstermektedir 
$(14,15)$. Düşük sosyo-ekonomik durum, KBY’de kötü sağlık sonuçlarıyla da ilişkilendirilmektedir (16). Düşük eğitim düzeyi, hastaların uygulamaları gereken diyetleri ve tedavilerinin bir parçası olan fosfat bağlayıcı ajan gibi medikal tedavilerini aksatmalarına ve/veya önemini yeterince anlayamamaları nedeniyle diyet ve medikal tedavilerini uygulamada zorluk yaşamalarına yol açmaktır (16). Diğer yandan düşük sosyo-ekonomik statü KBY'nin bir komplikasyonu olan PEM’in görülme sıklığını da arttırmaktadır (17).

HD alan SDBY hastalarında malnütrisyon gelişmesi durumunda malnütrisyonun geri döndürülmesi oldukça güç olmaktadır. Düşük eğitim ya da gelir seviyesi gibi malnütrisyon riskinin artmasina neden olabilecek olası sosyo-demografik risk faktörlerinin tanımlanması, yüksek riskaltında olan hastaların daha önceden belirlenmesi ve erken müdahale edilmesi açısından önemlidir. Bu çalışma, HD hastalarında malnütrisyon durumunu değerlendirmek ve sosyodemografik özelliklerin malnütrisyon riski üzerindeki etkilerini belirlemek amacıyla yapılmıştır.

\section{BİREYLER VE YÖNTEM}

Bu çalışma, Nisan-Mayıs 2017 tarihleri arasında özel bir diyaliz merkezinde gerçekleştirilmiştir. Çalışmaya en az 6 aylık sürede haftada bir, iki ve üç defa, dört saat süre ile HD’ye giren, 23-85 yaş arasında olan 57'si erkek (\%44.5), 71’i (\%55.5) kadın toplam 128 gönüllü hasta katılmıştır. Örnekleme, sorulara yanıt verecek yeterlilikte olan, KBY tanısı ile en az 6 aydır HD diyaliz tedavisi alan 18 yaş üzeri yetişkin bireyler dahil edilmiştir. Akut böbrek hasarı olan, çalışma öncesi (son bir ay) akut enfeksiyonu olan, kanser, karaciğer hastalığı vb. nütrisyonel durumu etkileyecek kronik hastalığı olan hastalar çalışma dışında bırakılmıştır. Toplamda 216 hasta taranmış ancak 88 hasta dahil edilme kriterlerini karşılamadığı veya çalışmaya katılmayı kabul etmediği için çalışmadan çıkarılmıştır. Çalışma için Başkent Üniversitesi Tıp ve Sağlık Bilimleri Araştırma Etik Kurulu'ndan KA17/107 nolu 17/41 sayll 19.04.2017 tarihli etik kurul onayı alınmıştır.

\section{Verilerin Toplanması ve Değerlendirilmesi}

Çalışmaya katılan hastaların sosyo-demografik özelliklerini, genel sağllk bilgilerini ve beslenme alışkanlıklarını saptamak amacıyla yüzyüze görüşme yöntemi ile anket formu uygulanmıştır. Hastaların antropometrik ölçümleri (boy ve vücut ağırlığı) alınmış ve beden kütle indeksi (BKİ, $\mathrm{kg} / \mathrm{m}^{2}$ ) hesaplanmıştır. Hastaların vücut ağırlığı, diyaliz çıkışındaki ödemsiz vücut ağırlığı (kuru ağırlık) dikkate alınarak Tanita TBF-300 cihazı ile ölçülmüştür (18). Boy uzunluğu birey dik pozisyonda iken baş Frankfurt düzleminde, ayaklar topuklardan bitişik, sırt, kalça ve topuklar duvara değecek şekilde derin nefes aldırılarak esnemeyen mezura ölçülmüştür (19). Hastaların BKI’si kuru vücut ağırlığı kullanılarak hesaplanmıştır (20). Avrupa Böbrek Derneği ve Avrupa Diyaliz ve Organ Nakli Derneği'nin (ERA-EDTA) kllavuz önerilerine göre BKİ'si <23.0 kg/m² olan bireyler "zayıf” olarak değerlendirilmiştir (21).

Hastaların bazı biyokimyasal parametreleri (albumin, total demir bağlama kapasitesi) hasta dosyalarından alınmıştır. Total demir bağlama kapasitesi için son 3 aydaki değer, serum albümin düzeyi için son bir aydaki değer kaydedilmiştir. Uluslararası Renal Beslenme ve Metabolizma Derneği (ISNRM)'ne göre serum albumin konsantrasyonunun <3.8 g/dL'den olması "malnütrisyon" göstergesi olarak değerlendirilmiştir (8). Total demir bağlama kapasitesi ise malnütrisyon inflamasyon skorlamasındaki (Mİs) aralıklara göre değerlendirilmiştir (22).

Hastaların besin tüketim durumlarının değerlendirilmesi için üç günlük (bir günü diyaliz günü ve bir günü hafta sonu olmak üzere iki diyaliz dışı gün) besin tüketim kaydı alınmıştır. Diyaliz günü, hastanın son 24 saat içinde tükettiği tüm yiyecekler ve içecekler sorgulanarak, ölçü ve miktarları fotoğraflı yemek ve besin kataloğu kullanılarak araştırmacı tarafından yüz yüze görüşme yöntemi ile alınmıştır (23). Günlük diyetle alınan enerji ve besin ögeleri, Türkiye için geliştirilen Beslenme Bilgi Sistemleri Paket Programı (BeBiS 8.1) kullanılarak analiz edilmiştir (24). Vücut ağırlığının kilogramı başına alınan enerji 
ve protein alımları, Amerika Birleşik Devletlerinde Ulusal Böbrek Vakfı'nın Böbrek Hastalığı Sonuçları Kalite Girişimi (NKF-KDOQI) kılavuzuna göre HD hastalarının alması gereken enerji ve protein miktarı ile karşılaştırılmıştır. Hastaların alması gereken enerji miktarı <60 yaş için 35 kkal/kg/gün, 60 yaş s için 30-35 $\mathrm{kkal} / \mathrm{kg} /$ gün olarak belirtilmiştir. Protein miktarının $<1.2 \mathrm{~g} / \mathrm{kg} /$ gün olması malnütrisyon için risk olarak değerlendirilmiştir (25).

Bireylerin malnütrisyon riskini değerlendirmek amacıyla Subjektif Global Değerlendirme (SGD), Nutrisyonel Risk Taramasi-2002 (NRS-2002) ve Malnütrisyon İnflamasyon Skoru (Mİs) kullanılmıştır. SGD formunda, hastalık öyküsünün ve fiziki muayene sonuçlarının skorlandığı iki ana başlık bulunmaktadır (26). Fiziki muayene hekim tarafından yapılmıştır. Sonuçlar skorlandıktan sonra hastalar: " $\mathrm{A}=$ iyi beslenmiş", " $\mathrm{B}=$ orta derecede malnutrisyon" veya " $\mathrm{C}=$ ağır malnutrisyon" olarak sınıflandırılmıştır (26). NRS-2002 ön tarama ve esas tarama olarak iki temel bölümden oluşmaktadır (27). Ön tarama bölümünde BKİ, son üç aydaki ağırlık kaybı, son hafta içindeki besin alımı durumunun azalması ve hastalık düzeyi (yoğun bakım hastası gibi) sorgulandıktan sonra bu parametrelerden birine verilen cevabin olumlu olması halinde esas tarama ile devam edilmiştir. Esas tarama kısminda beslenme durumunda bozulma durumu ve hastalığın şiddetinin derecesine göre hastanın yaşı da gözetilerek toplam NRS puanı hesaplanmıştır. Buna göre $\geq 3$ puan alanlar "beslenme riski var" olarak, <3 puan alanlar ise "beslenme riski yok" olarak değerlendirilmiştir (27). Mis ise on adet parametrenin her birinin " $0=$ normal" ve "3= en şiddetli” olmak üzere dört farklı kategoride değerlendirildiği bir skorlamadır (22). Skorlama, hastanın son 3-6 aydaki kuru ağırlık değişimi, diyet durumu, gastrointestinal semptomların varlığı, fonksiyonel kapasitesi, komorbid durumlar, cilt altı yağ dokusu, kas erimesi gibi fizik muayene ve BKİ, serum albumin düzeyi ve serum total demir bağlama kapasitesinin değerlendirilmelerini içerir. On adet MİS parametresinin toplamı " $0=$ normal" ile " $30=$ ăgrr malnütrisyon” arasında değişmektedir. Mís sonucuna göre toplam skor ne kadar yüksekse, hastanın malnütrisyon ve inflamasyon şiddetinin de o kadar yüksek olduğu kabul edilmektedir (22).

\section{Verilerin İstatistiksel Değerlendirilmesi}

İstatistiksel analizler SPSS (verisyon 21.0 IBM, USA) programı kullanılarak yapılmıştır (28). Normal dağılıma sahip veriler $\mathrm{X}_{ \pm}^{-}$SS şeklinde, normal dağılıma sahip olmayan veriler ise ortanca (çeyrek değerler) ile gösterilmiştir. Nitel değişkenler arasındaki analizlerde Pearson ya da Fisher Exact ki-kare testinden faydanılmıştır. Parametrik test koşullarının sağlandığı durumlarda iki grubun karşılaştırılması amacıyla Student's t-testi, sağlanamadığı durumlarda ise Mann-Whitney U testi kullanılmıştır. İki sayısal değişken arasındaki ilişki "Pearson korelasyon analizi” ve "Spearman korelasyon analizi” ile yapılmıştır. Sonuçlar \%95 güven aralığında, istatistiksel olarak önemlilik ise $\mathrm{p}<0.05$ düzeyinde değerlendirilmiştir.

\section{BULGULAR}

Araştırmaya, yaş ortalaması $58.9 \pm 13.2$ yıl olan toplam 128 hasta (71 kadın, \%55.5) katılmıştır. Hastaların \%15.6'sının okur yazar olmadığı, \%53.2'sinin okuryazar ya da ilkokul mezunu olduğu, \%74.2'sinin evli olduğu, \%92.2'sinin çalışmadığı saptanmıştır (Tablo 1). Eğitim düzeyi, medeni durum ve çalışma durumu açısından kadın ve erkekler arasında anlamlı farklılık bulunmaktadır ( $\mathrm{p}<0.05)$. Ayrıca, hastaların \%46.1'inde gelir-gider durumunun aynı olduğu, \%39.1'nde ise gelirinin giderinden az olduğu, \%93.8'inin kentte, \%6.3'ünün kirsal bölgede, \%89.0’unun ailesi ile, \%11.0'inin ise yalnız veya bakıcısı ile yaşadığı belirlenmiştir (Tablo 1).

Hastaların \%58.6’sının üç ana öğün, \%41.4'ünün 2 ana öğün tükettiği belirlenmiştir. Genelde atlanan öğün ara öğünler (\%52.4) ve öğle öğünüdür (\%33.0). Öğün atlama nedenleri arasında en sik beyan edilen neden olarak öğün sıklığının fazla gelmesi (\%32.3) ve hazırlayamama (\%31.4) yer almaktadır (Tablo 2). Diyaliz alma ve hastalık durumuna özgü diyet uygulama durumu değerlendirildiğinde, hastaların 
Tablo 1. Öğrencilerin beslenme eğitimi öncesi ve sonrası fiziksel aktivite yapma durumlarının IPAQ’a göre değerlendirilmesi

\begin{tabular}{|c|c|c|c|c|c|c|c|}
\hline \multirow{2}{*}{ Değişken } & \multicolumn{2}{|c|}{ Kadın (n=71) } & \multicolumn{2}{|c|}{ Erkek $(n=57)$} & \multicolumn{2}{|c|}{ Toplam $(n=128)$} & \multirow{2}{*}{$\boldsymbol{X}^{2}, \boldsymbol{p}$} \\
\hline & $\mathbf{S}$ & $\%$ & S & $\%$ & $\mathbf{S}$ & $\%$ & \\
\hline \multicolumn{8}{|l|}{ Eğitim Durumu } \\
\hline Okuryazar olmayan & 18 & 25.4 & 2 & 3.5 & 20 & 15.6 & \multirow{6}{*}{$\begin{aligned} X^{2} & =28.372^{\mathrm{x}} \\
\mathrm{p} & =0.000^{*}\end{aligned}$} \\
\hline Okuryazar & 6 & 8.5 & 1 & 1.8 & 7 & 5.5 & \\
\hline İlkokul & 37 & 52.1 & 24 & 42.1 & 61 & 47.7 & \\
\hline Ortaokul & 5 & 7.0 & 11 & 19.3 & 16 & 12.5 & \\
\hline Lise & 3 & 4.2 & 11 & 19.3 & 14 & 10.9 & \\
\hline Üniversite & 2 & 2.8 & 8 & 14.0 & 10 & 7.8 & \\
\hline \multicolumn{8}{|l|}{ Medeni Durum } \\
\hline Evli & 49 & 69.0 & 46 & 80.7 & 95 & 74.2 & \multirow{3}{*}{$\begin{aligned} X^{2} & =8.391^{0} \\
\mathrm{p} & =0.015^{*}\end{aligned}$} \\
\hline Bekar & 4 & 5.6 & 7 & 12.3 & 11 & 8.6 & \\
\hline Dul/Boşanmış & 18 & 25.4 & 4 & 7.0 & 22 & 17.2 & \\
\hline \multicolumn{8}{|l|}{ Çalışma durumu } \\
\hline Çalışıyor & - & - & 10 & 17.5 & 10 & 7.8 & $X^{2}=13.512^{0}$ \\
\hline Çalışmıyor & 71 & 100.0 & 47 & 82.5 & 118 & 92.2 & $\mathrm{p}=0.001^{*}$ \\
\hline
\end{tabular}

opearson ki-kare istatistik değeri, ${ }^{\prime}$ Fisher'n kesin ki kare testi; ${ }^{*} p<0.05$

Tablo 2. Hastaların cinsiyete göre ana ve ara öğün tüketim durumları

\begin{tabular}{|c|c|c|c|c|c|c|c|}
\hline \multirow{2}{*}{ Değişkenler } & \multicolumn{2}{|c|}{ Kadın (n=71) } & \multicolumn{2}{|c|}{ Erkek $(n=57)$} & \multicolumn{2}{|c|}{ Toplam $(n=128)$} & \multirow{2}{*}{$X^{2}, p$} \\
\hline & $\mathbf{S}$ & $\%$ & $\mathbf{S}$ & $\%$ & $\mathbf{S}$ & $\%$ & \\
\hline \multicolumn{8}{|l|}{ Günlük ana öğün sayısı } \\
\hline 2 & 31 & 43.7 & 22 & 38.6 & 53 & 41.4 & $X^{2}=0.334$ \\
\hline 3 & 40 & 56.3 & 35 & 61.4 & 75 & 58.6 & $\mathrm{p}=0.563$ \\
\hline \multicolumn{8}{|l|}{ Günlük ara öğün sayısı } \\
\hline Hiç & 4 & 5.6 & 6 & 10.5 & 10 & 7.8 & \\
\hline 1 & 41 & 57.8 & 23 & 40.4 & 64 & 50.0 & $X^{2}=4.309^{x}$ \\
\hline 2 & 25 & 35.2 & 27 & 47.4 & 52 & 40.6 & $\mathrm{p}=0.197$ \\
\hline 3 & 1 & 1.4 & 1 & 1.8 & 2 & 1.6 & \\
\hline \multicolumn{8}{|l|}{ Genelde Atlanan Öğün ${ }^{\gamma}$} \\
\hline Sabah & 7 & 10.0 & 7 & 12.7 & 14 & 6.6 & \\
\hline Öğle & 43 & 61.4 & 27 & 49.1 & 70 & 33.0 & \\
\hline Akşam & 8 & 11.4 & 9 & 16.4 & 17 & 8.0 & \\
\hline Ara öğünler & 60 & 85.7 & 51 & 92.7 & 111 & 52.4 & \\
\hline \multicolumn{8}{|l|}{ Öğün Atlama Nedeni ${ }^{\gamma}$} \\
\hline Zamanı yok & 4 & 5.7 & 3 & 5.5 & 7 & 2.2 & \\
\hline İştahsız & 45 & 64.3 & 32 & 58.2 & 77 & 23.9 & \\
\hline Hazırlayamadığı için & 60 & 85.7 & 41 & 74.5 & 101 & 31.4 & \\
\hline Alışkanlığı yok & 19 & 27.1 & 14 & 25.5 & 33 & 10.2 & \\
\hline Öğün sıklığı fazla & 57 & 81.4 & 47 & 85.5 & 104 & 32.3 & \\
\hline
\end{tabular}

opearson ki-kare istatistik değeri, ${ }^{\text {} F i s h e r ' n ~ k e s i n ~ k i-k a r e ~ t e s t i ; ~}{ }^{*} p<0.05$

vöğün atlayan hastaların " $n$ ” sayısı üzerinden \% hesaplanmıştır.

\%75’inin diyet uygulamadığı, diyalize özgü diyet uygulayan hastaların (\%25) ise diyeti aldığı kaynağın en sık matbu kağıt olduğu belirlenmiştir (tabloda gösterilmemiştir). 
Tablo 3. Hastaların cinsiyete göre SGD, NRS-2002 sonuçlarının dağılımı ve Mís sonuçlarının medyan ve çeyrek değerleri

\begin{tabular}{|c|c|c|c|c|c|c|c|}
\hline \multirow{2}{*}{ Ölçekler } & \multicolumn{2}{|c|}{ Kadın $(n=71)$} & \multicolumn{2}{|c|}{ Erkek $(n=57)$} & \multicolumn{2}{|c|}{ Toplam $(n=128)$} & \multirow{2}{*}{$X^{2}, p$} \\
\hline & $\mathbf{S}$ & $\%$ & $\mathbf{S}$ & $\%$ & $\mathbf{S}$ & $\%$ & \\
\hline \multicolumn{8}{|l|}{ SGD } \\
\hline İyi beslenmiş & 55 & 77.5 & 42 & 73.7 & 97 & 75.8 & \multirow{3}{*}{$\begin{aligned} X^{2} & =1.244 \\
p & =0.537\end{aligned}$} \\
\hline Hafif-orta malnütrisyon & 9 & 12.7 & 11 & 19.3 & 20 & 15.6 & \\
\hline Ağır malnütrisyon & 7 & 9.8 & 4 & 7.0 & 11 & 8.6 & \\
\hline \multicolumn{8}{|l|}{ NRS-2002 } \\
\hline Malnütrisyon riski var & 16 & 22.5 & 12 & 21.1 & 28 & 21.9 & $X^{2 x}=0.041$ \\
\hline Malnütrisyon riski yok & 55 & 77.5 & 45 & 78.9 & 100 & 78.1 & $\mathrm{p}=0.840$ \\
\hline MIS & \multicolumn{2}{|c|}{$\begin{array}{l}\text { Medyan } \\
\text { (Q1-Q3) }\end{array}$} & \multicolumn{2}{|c|}{$\begin{array}{l}\text { Medyan } \\
\text { (Q1-Q3) }\end{array}$} & \multicolumn{2}{|c|}{$\begin{array}{l}\text { Medyan } \\
\text { (Q1-Q3) }\end{array}$} & \\
\hline MIS değeri & \multicolumn{2}{|c|}{$\begin{array}{c}6.0 \\
(5.0-9.0)\end{array}$} & \multicolumn{2}{|c|}{$\begin{array}{c}5.0 \\
(3.5-9.0)\end{array}$} & \multicolumn{2}{|c|}{$\begin{array}{c}6.0 \\
(4.0-9.0)\end{array}$} & $\begin{array}{l}\mathrm{U}=1695 \\
\mathrm{p}=0.113\end{array}$ \\
\hline
\end{tabular}

${ }^{\circ}$ Pearson ki-kare testi * ${ }^{*}<0.05$, SGD: Subjektif Global Değerlendirme, NRS-2002: Nutrisyonel Risk Skoru 2002, Mİs: Malnütrisyon İnflamasyon Skoru, Q: Çeyreklikler

Tablo 4. Hemodiyaliz hastalarında malnütrisyon ile ilişkili parametrelere göre Mís medyan değeri ve çeyrek değerler

\begin{tabular}{|c|c|c|c|c|c|c|}
\hline \multirow{2}{*}{ Değişkenler } & \multirow[b]{2}{*}{$\mathbf{S}$} & \multirow[b]{2}{*}{$\%$} & \multicolumn{3}{|c|}{ MİS değeri } & \multirow{2}{*}{$U, p$} \\
\hline & & & Medyan & Q1 & Q3 & \\
\hline \multicolumn{7}{|l|}{ BKİ $\left(\mathbf{k g} / \mathbf{m}^{2}\right)$} \\
\hline$<23$ & 52 & 40.6 & 8 & 6 & 11 & $\mathrm{U}=1050.5$ \\
\hline$\geq 23$ & 76 & 59.4 & 5 & 4 & 7 & $\mathrm{p}=0.000^{*}$ \\
\hline \multicolumn{7}{|c|}{ Enerji alımı (kkal/kg/gün) } \\
\hline \multicolumn{7}{|c|}{ <35 (<60 yaş için) } \\
\hline <30-35 ( $\geq 60$ yaş için) & 102 & 79.7 & 6 & 4 & 8 & $\mathrm{U}=829.5$ \\
\hline$\geq 35$ (<60 yaş için) & & & & & & $\mathrm{p}=0.003^{*}$ \\
\hline 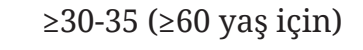 & 26 & 20.3 & 8 & 5.8 & 11 & \\
\hline \multicolumn{7}{|l|}{ Protein alımı (g/kg/gün) } \\
\hline$<1.2$ & 100 & 78.1 & 6 & 4 & 8.75 & $\mathrm{U}=1053$ \\
\hline$\geq 1.2$ & 28 & 21.9 & 8 & 5 & 9.75 & $\mathrm{p}=0.044^{*}$ \\
\hline \multicolumn{7}{|l|}{ Albumin (g/dL) } \\
\hline$<3.8$ & 28 & 21.9 & 8 & 6 & 10.75 & $\mathrm{U}=728.5$ \\
\hline$\geq 3.8$ & 100 & 78.1 & 5 & 4 & 8 & $\mathrm{p}=0.000^{*}$ \\
\hline
\end{tabular}

${ }^{*} p<0.05$ Mann Whitney U testi.

BKİ: Beden kütle indeksi, MIS: Malnütrisyon İnflamasyon Skoru, Q: Çeyreklikler

Tablo 3'te hastaların cinsiyete göre SGD, NRS-2002 sonuçlarının dağılımı ve Mís sonuçlarının medyan ve çeyreklik değerleri gösterilmiştir. SGD’ye göre hastaların \%15.6'sı hafif-orta derece malnütrisyonlu ve \%8.6'sı ağır derecede malnütrisyonludur. NRS2002 sonuçlarına göre ise hastaların \%21.9'unda malnütrisyon riski olduğu belirlenmiş ve cinsiyetler arasında tarama testlerine göre malnütrisyon varlığ ve dereceleri açısından önemlifarklılık bulunmamıştır
( $p>0.05$ ). MIS medyan değeri toplamda 6 puan olarak saptanmıştır (Tablo 3).

Hastaların \%59.4'ünün BKİ değeri $>23 \mathrm{~kg} / \mathrm{m}^{2}$ 'dir ve medyan MIS skoru, BKI $<23 \mathrm{~kg} / \mathrm{m}^{2}$ olan hastalara göre daha düşüktür $(\mathrm{p}<0.05)$. Hastaların \%79.7’sinde diyetle günlük enerji alımının, \%78.1’inde ise diyetle protein alımının önerilenin altında olduğu saptanmıştır. Serum albümin düzeyi katılımclların \%78.1'inde 


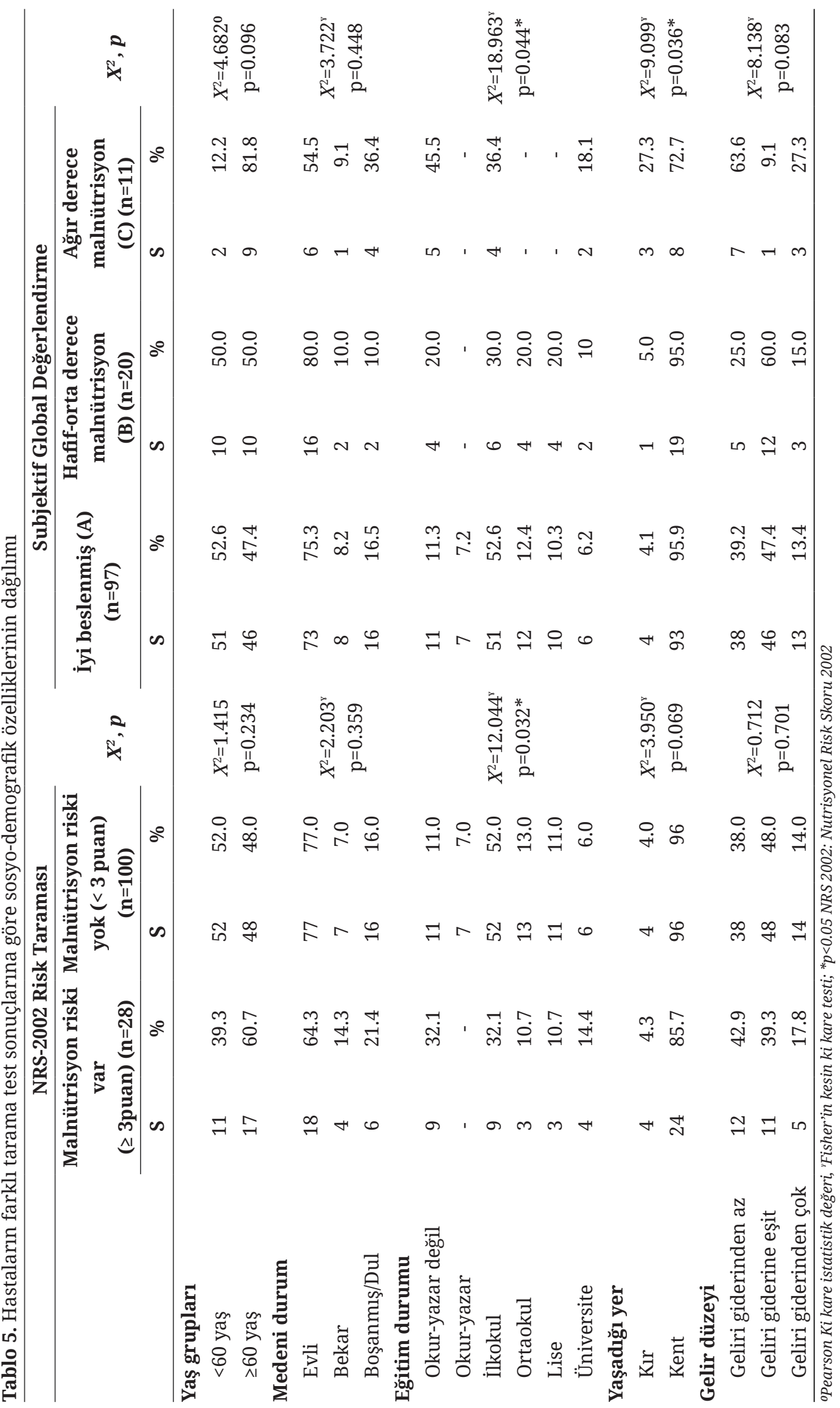


$>3.8 \mathrm{~g} / \mathrm{dL}$ 'dir ve serum albümini <3.8 g/dL olanların medyan Mİs skoru, albümin düzeyi $\geq 3.8 \mathrm{~g} / \mathrm{dL}$ olanlara göre anlamlı olarak daha yüksektir ( $\mathrm{p}<0.05$ ) (Tablo 4).

Hastaların farklı tarama test sonuçlarına göre sosyo-demografik özelliklerinin dağılımı Tablo 5'te gösterilmiştir. NRS-2002'ye göre malnütrisyon riski olan hastaların \%64.2'sinin ilkokul ve altı eğitim düzeyine sahip olduğu görülmüştür. Benzer şekilde, SGD’ye göre hafif-orta derece malnütrisyonu olan hastalarınyarısınınilkokulvealtıeğitim düzeyinesahip olduğu, ağır derece malnütrisyonlu olan hastaların \%45.5’inin okur-yazar olmadığı, \%36.4'ünün ilkokul mezunu olduğu saptanmıştır. Hastaların eğitim düzeylerine göre malnütrisyon durumları arasında anlamlı farklılık olduğu belirlenmiştir $(p<0.05)$. MIS ile demografik özelliklerden yaş, eğitim durumu, gelir düzeyi arasında ilişki bulunamamıştır ( $p>0.05)$ (veriler tabloda gösterilmemiştir).

\section{TARTIŞMA}

HD hastalarının demografik özelliklerine göre beslenme durumlarının değerlendirildiği bu araştırmada hastaların \%68.8'inin, eğitim seviyesinin ilkokul ve altında düzeyde olduğu saptanmıştır. Elmas ve ark. (29) bu hasta grubunun \%80.0'inin, Çavuş (30) ise \%74.9'unun ilkokul ve altında eğitim düzeyine sahip olduğunu saptamıştır. Hastaların çoğunlukla öğünleri hazırlamada zorluk ve öğün sıklığının fazla gelmesi gibi nedenlerle öğün atladığı, en sık atlanan öğünlerin ise ara öğünler ve öğle öğünü olduğu belirlenmiştir (Tablo 2). Yılmaz (31), hastaların \%56.7'sinin ara öğünü, Elibol (32) tokluk hissi ve geç kahvaltı nedeniyle \% 71.4’ünün öğle öğününü atladıklarını, Öztürk (33) ise hastaların ara öğün saatlerinde HD almaları, biyokimyasal bulgularının kötü çıkmasındaki kaygıları nedeniyle öğün atladıklarını saptamıştır. Hastaların öğün atlama nedeni, iştahsızlıktan, diyaliz seansı sonrası yorgun olmalarından dolayı besinleri hazırlama ve pişirmede yaşadığı zorluklardan, seans sirasinda tükettikleri besinlerden dolayı tokluk hissinden kaynaklanabilmektedir. Diğer taraftan, \%75.0’i diyalize ve hastalık durumlarına özgü diyet uygulamamaktadır (Tablo 2). Yapılan diğer araştırmalar da bu hasta grubunun aldıkları medikal tedaviye ve hastalık durumlarına göre uygulamaları gereken diyete uyumda sorun yaşadığını göstermiştir $(30,34)$. Bu çalışmada, hastaların büyük çoğunluğunun eğitim düzeylerinin düşük olması nedeniyle diyet uygulamalarının önemini yeterince kavrayamamış olmaları ve diyet kısıtlamaları dolayısıyla besin seçeneklerinin az olmasının diyete uyumsuzluğun temel nedenleri arasında olduğu düşünülmektedir. Bunun yanı sıra hastalığa özgü diyet uyguladığını bildirenlerin diyet kaynağının en sık matbu olduğu görülmektedir. Matbuda hemodiyaliz hastalarının kısıtll tüketebilecekleri ve serbest tüketebilecekleri besinlerin listesi yer almaktadır fakat hastalar diyetisyen tarafindan planlanan kişiselleştirilmiş tıbbi beslenme tedavisi almamaktadır. Eğitim düzeyi düşük olan bu hasta grubunun diyetisyen tarafından beslenme eğitimi almaması çeşitli beslenme sorunlarına neden olmaktadır. Diyetisyen tarafından tasarlanmış diyet, beslenme eğitimi, hasta ile geçirilen zaman hastaların beslenme durumlarında iyileşme ile pozitif ilişkilidir (35).

Hastalarm tarama testlerine (Tablo 3) ve BKİ, serum albümin, enerji ve protein alımları gibi malnütrisyon ile ilişkili parametrelere göre (Tablo 4) malnütrisyon oranları farklılık göstermektedir. Literatürde de, hemodiyaliz hastalarında malnütrisyon risklerinin varlığı ve derecesi ile ilişkili oranların değerlendirme kriterlerindeki çeşitlilik nedeniyle farklılık gösterdiği görülmektedir (36-38). HD hastalarında PEM sıklıkla görülen bir durumdur ve erken tanımlanması mortalitenin azaltılması açısından önem taşımaktadır (7). Tarama aracı beslenme problemleriniiyibir şekilde tanımlayabilmeli, morbidite ve mortalite risklerini tahmin edebilmeli, beslenme müdahalesi gerektiren hastaları belirleyebilmeli ve hastaların beslenme tedavisine yanıtlarını değerlendirebilmelidir; bunun yanı sıra geçerli, güvenilir, basit, ucuz ve pratik olmalıdır $(39,40)$. Bu bağlamda Mís’in diğer tarama araçlarına göre malnütrisyonun tahmininde ve saptanmasinda SGD’ye göre daha iyi bir belirteç olduğu bildirilse de HD hastalarında malnütrisyon 
riskini ve varlığını belirleyen altın standart niteliğinde bir tarama aracı veya belirteç bulunmamaktadır $(34,41,42)$. Çalışmada tartışmalı bulgulardan bir tanesi de MİS skorunun, malnütrisyonun göstergesi sayılabilecek BKİ ve albumin düzeyleri ile ters ilişkili olmasına rağmen, enerji ve protein alımları ile pozitif ilişkili olmasıdır. Benzer şekilde hastaların \%80'inin diyetle enerji ve protein alımları önerilerin altında olmasına karşın; SGD ve NRS-2002 tarama aracına göre malnütrisyon riskinde olanlar \%80'nin altındadır. Bu durumun, malnütrisyonlu hastaların besin tüketim kayıtları sırasında tükettiği besinlerin miktarlarını tam olarak hatırlayamaması ve tükettiği besinler ve miktarları hakkında eksik ya da fazla beyanda bulunmasından kaynaklandığı düşünülmektedir. Ayrıca, malnütrisyonlu hastaların enteral solüsyon takviyesi kullanmak istemedikleri için herhangi bir besini tüketmedikleri halde, besin tüketim kayıdı sırasında tükettiğini belirtmiş olabileceği düşünülmektedir. Buna ek olarak, hastaların diyaliz dışı günler tükettiği besinleri yanlış bildirme olasılığı da yüksek olabilmektedir. Ayrıca, diyaliz gününde alınan kayıtta tedaviye bağlı olarak depresif, sinirli ve endişeli oldukları için hastalarla iletişim kurmada zorluk yaşanması nedeniyle enerji ve protein alımlarına ilişkin sonuçların çelişkili olabileceği düşünülmektedir. Albümin de yarllanma ömrünün uzun olması sebebiyle akut malnütrisyonu göstermede yetersizdir. Hemodiyalizdeki karıştırıcı faktörler biyokimyasal testlerin duyarlılığı ve özgüllüğü üzerinde etkilidir. $\mathrm{Bu}$ nedenle malnütrisyonun belirlenmesinde biyokimyasal ve antropometrik bulgular ile birlikte HD hastalarına özgü tasarlanmış besin tüketim kayıt formu ve tarama araçlarının birlikte kullanılması gerekmektedir.

$\mathrm{Bu}$ araştırmada malnütrisyonu veya malnütrisyon riski olan hastaların eğitim düzeyinin düşük olduğu ve malnütrisyon risk düzeyine göre eğitim düzeyleri arasında farklılık saptanmıştır. Başka bir araştırmada da, hastaların \%59'unun ilkokul ve altı eğitim düzeyine sahip olduğu, eğitim seviyesi düşük hastalarda, eğitim seviyesi yüksek olan hastalara göre malnütrisyon prevalansının daha yüksek olduğu saptanmıştır.
Ayrıca, hastaların büyük bir çoğunluğunun gelir düzeylerinin düşük olduğu, malnütrisyon oranlarının yüksek olduğu belirlenmiştir. Literatürdeki diğer araştırmalar bu çalışmayı desteklemektedir ve düşük sosyo-ekonomik statünün malnütrisyona neden olduğunu göstermektedir (14-17,43).

$\mathrm{Bu}$ araştırmanın bazı sinırlılıkları bulunmaktadır. Çalışmanın kesitsel olması nedeniyle incelenen faktörler ile beslenme durumu arasindaki uzunlamasına ilişkilerin kuralamaması, örneklem sayısının düşük olması, demografik özelliklerin belirlenmesinde geçerli ve güvenilir bir aracın kullanılmaması, hastaların besin tüketim kayıtları alınırken 24 saatlik hatırlama yöntemi yerine kayıt yöntemi kullanılmasına rağmen hastaların tükettikleri besinleri, içeriklerini ve miktarlarını hatalı bildirme olasılığı ve aldıkları diyaliz tedavisine bağlı olarak iletişim kurmada sorun yaşanması gibi nedenlerle toplam enerji ve protein alımlarının hesaplanmasındaki hatalar bu sinırlılıklar arasında yer almaktadır.

Sonuç olarak, HD hastalarının büyük çoğunluğunu sosyo-ekonomik düzeyi düşük bireylerin oluşturduğu görülmektedir. HD hastaları hastalığın kendisi, eşlik eden hastalıklar ve diyalizin etkisi nedeniyle malnütrisyon riski altındadır. Sosyo-ekonomik düzeyin düşük olması da hastaların beslenme durumlarını olumsuz etkilemektedir. Malnütrisyonun erken saptanması ve monitörizasyonu amacıyla besin tüketiminin, antropometrik ve biyokimyasal parametrelerinyanısırasağlığınsosyalbelirleyicilerini de içeren, HD hastalarına yönelik tasarlanmış, geçerliliği ve güvenilirliği olan bir tarama testinin gerekli olduğu görülmüştür. Malnütrisyon riskleri belirlendikten sonra tıbbi beslenme tedavisinin bir parçası olan eslenme eğitiminde seçilecek yöntem hastaların sosyo-demografik özellikleri de gözetilerek belirlenmelidir.

Çıkar çatışması - Conflict of interest: Yazarlar çıkar çatışması olmadığını beyan ederler. - The authors declare that they have no conflict of interest. 


\section{KAYNAKLAR}

1. T.C Sağlık Bakanlığı Türkiye Böbrek Hastalıkları Önleme ve Kontrol programı 2014-2017. Yayın No: 946. Erişim: https://sbu.saglik.gov.tr/Ekutuphane/Yayin/503 Erişim tarihi: 10 Ekim 2019.

2. Centers for Disease Control and Prevention. Chronic Kidney Disease Surveillance System-United States. Available at: https://nccd.cdc.gov/CKD/ Accessed October 12, 2019.

3. Süleymanlar G, Utaş C, Arinsoy T, Ateş K, Altun B, Altiparmak MR, et al. A population-based survey of Chronic Renal Disease in Turkey-the CREDIT study. Nephrol Dial Transplant. 2010;26(6):1862-71.

4. Initiative KDOQ. Kidney disease outcomes quality initiative (K/DOQI) clinical practice guidelines for chronic kidney disease: evaluation, classification, and stratification. Am J Kidney Dis. 2002;39(2 Suppl 1):S1S266.

5. Baysal A, Aksoy M, Besler H, Bozkurt N, Keçecioğlu S, Merdol T, et al. Diyet El Kitabı. 5. baskı. Ankara: Hatipoğlu Yayınevi. 2008. s67-143.

6. Süleymanlar G, Ateş K, Seyahi N. Türkiye'de Nefroloji, Diyaliz ve Transplantasyon 2017. T.C Sağlık Bakanlığı ve Türk Nefroloji Derneği Ortak Raporu. İstanbul: Türk Nefroloji Derneği; 2018.

7. Fouque D, Kalantar-Zadeh K, Kopple J, Cano N, Chauveau P, Cuppari L, et al. A proposed nomenclature and diagnostic criteria for protein-energy wasting in acute and chronic kidney disease. Kidney Int. 2008;73(4):3918.

8. Ikizler TA, Cano NJ, Franch H, Fouque D, Himmelfarb J, Kalantar-Zadeh K, et al. Prevention and treatment of protein energy wasting in chronic kidney disease patients: a consensus statement by the International Society of Renal Nutrition and Metabolism. Kidney Int.2013;84(6):1096-107.

9. Kovesdy CP. Malnutrition in dialysis patients - the need for intervention despite uncertain benefits. Semin Dial. 2016;29(1):28-34.

10. Rocco MV, Paranandi L, Burrowes JD, Cockram DB, Dwyer JT, Kusek JW, et al. Nutritional status in the HEMO study cohort at baseline. Am J Kidney Dis. 2002;39(2):245-56.

11. Ekramzadeh M, Mazloom Z, Jafari P, Ayatollahi M, Sagheb MM. Major barriers responsible for malnutrition in hemodialysis patients: challenges to optimal nutrition. Nephrourol Mon. 2014;6(6):e23158.

12. Freitas AT, Vaz IM, Ferraz SF, Peixoto MD, Campos MI. Prevalence of malnutrition and associated factors in hemodialysis patients. Rev Nutr. 2014;27(3):357-66.

13. Agboton B, Agueh V, Vigan J, Sourou B, Ahoui S. Assessing the nutritional status of hemodialysis patients in a subsaharan country. J Kidney. 2017;3(2).

14. Ward FL, O’Kelly P, Donohue F, O’Haiseadha C, Haase T, Pratschke J, et al. The influence of socioeconomic status on patient survival on chronic dialysis. Hemodial Int. 2015;19(4):601-8.

15. Kimmel PL, Fwu CW, Eggers PW. Segregation, income disparities, and survival in hemodialysis patients. J Am Soc Nephrol. 2013;24(2):293-301.

16. Santoro D, Ingegnieri MT, Vita G, Lucisano S, Zuppardo C, Canale V, et al. Socio-economic factors, food habits and phosphorus levels in patients on hemodialysis. Nephrourol Mon. 2015;7(4):e27114.

17. Kumar VA, Tilluckdharry N, Xue H, Sidell MA. Serum phosphorus levels, race, and socioeconomic status in incident hemodialysis patients. J Ren Nutr. 2016;26(1):107.

18. Levy J, Morgan J, Brown E. Oxford diyaliz el kitabı Ankara, Nobel Tip Kitabevleri; 2002. s598.

19. Gibson R. Food consumption of individual. Principles of nutritional assessment. 2nd ed. USA: Oxford University Press 2005. 908 p.

20. Diet W. Nutrition and the prevention of chronic diseases. Report of a joint WHO/FAO expert consultation. WHO Technical report series. 2003;916:34-8.

21. Fouque D, Vennegoor M, Ter Wee P, Wanner C, Basci A, Canaud B, et al. Raymond Vanholder EBPG Guideline on Nutrition Nephrol Dial Transplant. 2007;22(Suppl 2):ii45-ii87.

22. Kalantar-Zadeh K, Kopple JD, Block G, Humphreys MH. A malnutrition-inflammation score is correlated with morbidity and mortality in maintenance hemodialysis patients. Am J Kidney Dis. 2001;38(6):1251-63.

23. Rakıcıoğlu N, Tek Acar N, Ayaz A, Pekcan G. Yemek ve Besin Fotoğraf Kataloğu-Ölçü ve Miktarlar. Ata Ofset Matbaacılık, Ankara, 2009.

24. Beslenme Bilgi Sistemi- BeBiS, Versiyon 8.1; 2012, İstanbul.

25. Kopple J, Wolfson M, Chertow G. K/DOQI nutrition in chronic renal failure. Am J Kidney Dis. 2000;35(6 Suppl 2):1-140.

26. Steiber AL, Kalantar-Zadeh K, Secker D, McCarthy M, Sehgal A, McCann L. Subjective Global Assessment in chronic kidney disease: a review. J Renal Nutr. 2004;14(4):191-200.

27. Kondrup J, Allison SP, Elia M, Vellas B, Plauth M. ESPEN guidelines for nutrition screening 2002. Clin Nutr. 2003;22(4):415-21.

28. Corporation IBM. IBM SPSS statistics for windows, Version 21.0. IBM Corp Armonk; 2012.

29. Elmas A, Saral EE, Tuğrul A, Şengül E, Bünül F. 
Hemodializ hastalarında beslenme bilgi düzeyi ile klinik ve laboratuar bulguları arasındaki ilişki. Kocaeli Tıp Dergisi. 2012;1(3):23-6.

30. Çavuş Ö. Hemodiyaliz hastalarının tedaviye ve diyete uyumları ile yaşam kalitesi düzeylerinin değerlendirilmesi Türk Böbrek Vakfı Merkezi Örneği. [Bilim Uzmanlığı Tezi]. Namık Kemal Üniversitesi Sosyal Bilimler Enstitüsü. Tekirdağ; 2016.

31. Karahan-Yılmaz S. Hemodiyalize giren hastalarda beslenme durumu ile kas gücü arasındaki ilişkinin değerlendirilmesi. [Bilim Uzmanlığı Tezi]. Hacettepe Üniversitesi Sağlık Bilimleri Enstitüsü Ankara; 2012.

32. Elibol E. Yetişkin hemodiyaliz hastalarının plazma desacly ghrelin düzeyleri ile iştah ve beslenme durumları arasındaki ilişkinin değerlendirilmesi. [Bilim Uzmanlığı Tezi]. Gazi Üniversitesi Sağlık Bilimleri Enstitüsü Ankara; 2016.

33. Öztürk D. Hemodiyalize giren kronik böbrek yetmezliği olan hastaların yumurta ve yumurta akı tüketimlerinin bazı biyokimyasal ve hematolojik bulgular üzerine etkilerinin karşılaştırılması. [Bilim Uzmanlığı Tezi]. Başkent Üniversitesi Sağlık Bilimleri Enstitüsü Ankara; 2009.

34. Güneş BD. Hemodiyaliz tedavisi alan hastalarda farklı tarama testlerinin karşılaştırılması ve beslenme durumu ile ilişkilendirilmesi. [Bilim Uzmanlığı Tezi]. Gazi Üniversitesi Sağlık Bilimleri Enstitüsü Ankara; 2017.

35. Calegari A, Barros EG, Veronese FV, Thomé FS. Malnourished patients on hemodialysis improve after receiving a nutritional intervention. J Bras Nefrol. 2011;33(4):394-401.

36. Führ LM, Wazlawik E, Garcia MF. The predictive value of composite methods of nutritional assessment on mortality among haemodialysis patients. Clin Nutr. 2015;10(1):e21-e5.

37. Santin F, Rodrigues J, Brito FB, Avesani CM. Performance of subjective global assessment and malnutrition inflammation score for monitoring the nutritional status of older adults on hemodialysis. Clin Nutr. 2018;37(2):604-11.

38. Tan R, Long J, Fang S, Mai H, Lu W, Liu Y, et al. Nutritional Risk Screening in patients with chronic kidney disease. Asia Pac J Clin Nutr. 2016;25(2):249.

39. Borges MCC, Vogt BP, Martin LC, Caramori JCT. Malnutrition Inflammation Score cut-off predicting mortality in maintenance hemodialysis patients. Clin Nutr.2017;17:63-7.

40. Yamada K, Furuya R, Takita T, Maruyama Y, Yamaguchi Y, Ohkawa S, et al. Simplified nutritional screening tools for patients on maintenance hemodialysis. Am J Clin Nutr. 2008;87(1):106-13.

41. Pisetkul C, Chanchairujira K, Chotipanvittayakul N, OngAjyooth L, Chanchairujira T. Malnutrition-inflammation score associated with atherosclerosis, inflammation and short-term outcome in hemodialysis patients. J Med Assoc Thai. 2010;93(Suppl 1):S147-S56.

42. Türker PF. Böbrek Hastalıklarında Beslenme Durumunun Saptanması. Bes Diy Derg. 2018;46(Özel Sayı):30-5.

43. De Oliveira GTC, Andrade EIG, De Assis Acurcio F, Cherchiglia ML, Correia MITD. Nutritional assessment of patients undergoing hemodialysis at dialysis centers in Belo Horizonte, MG, Brazil. Rev Assoc Med Bras. 2011;58(2):240-7. 